\title{
多変量解析による貯血式自己血採血におけるエリスロポエチン製剤投与時の痛みの 因子同定
}

\author{
丸橋 隆行 ${ }^{1)}$ 横手 恵子 ${ }^{2)}$ 青山 千夏 ${ }^{2)}$ 堀越 晃輔 ${ }^{1)}$ 菅井 貴裕 ${ }^{1)}$ \\ 西本奈津美 ${ }^{1)}$ 須佐 $\quad$ 梢 $^{1)} \quad$ 関上 智美 ${ }^{13)}$ 橋本 $\quad$ 陽子 ${ }^{13)}$ 滝沢 牧子 ${ }^{133}$ \\ 横濱 章彦1)
}

自己血貯血時には $800 \mathrm{~m} l$ 以上の場合に限りエリスロポエチン製剤（erythropoiesis-stimulating agent, ESA）の使 用が認められている。最近になりエポエチン $\alpha(\mathrm{EPO} \alpha)$ に加えエポエチン $\beta(\mathrm{EPO} \beta)$ も上市され 2 種類の皮下注射 用 ESA 製剂が使用可能となったが， 2 剂間の投与時の痛みに差があることが以前より国内外から報告されている. 今回, 我々は自己血貯血患者に ESA を投与したときの痛みの関与する因子を解析した. ESA 投与時に Visual Analogue Scale（VAS）と Face Scale（FS）を患者が記載した．EPO $\alpha$ 群 100 名，EPOß 群 103 名，のべ投与回数 405 回を解析の対象とした１ 1 回目投与時の解析では EPO $\alpha$ 群は有意にVAS が高く $(p=0.0085)$, 投与全体 405 回の解 析でも同様であった $(p<0.0001)$. VAS を用いて多変量解析を行うと EPO $\alpha$ と女性が有意に痛みに関与していた. さらに ESA 製剤と性別で 4 群に分け解析すると，女性に EPO $\alpha$ を投与したときのみ有意にVAS が高かった，以上 より女性に $\mathrm{EPO} \alpha$ を投与する場合には配慮が必要であるが，その痛みの差はいずれの製凪を使っても少なくとも貯 血計画に影響を与えるほどのものではないと思われた。

キーワード：エポエチン $\alpha$ ，エポエチン $\beta$ ，エリスロポエチン製郕，赤血球造血因子製凨，

Visual Analogue Scale, Face Scale, 女性

\section{はじめに}

エリスロポエチン製剤（赤血球造血刺激因子製剤： erythropoiesis-stimulating agent, ESA) は 1990 年に透 析施行中の腎性貧血患者に対し保険適応となって以来, 多くの慢性腎臓病の患者に使用され貧血改善の効果を 示している.その後の検討で, ESA が自己血貯血に伴 う貧血への改善効果が明らかとなり ${ }^{122)}, 1993$ 年には貯 血量が $800 \mathrm{ml}$ 以上で 1 週間以上の貯血期間を予定して いる患者への自己血貯血について保険適応となった. 輸血療法の実施に関する指針では，待機的手術患者の 輸血について同種血回避の目的で自己血輸血を積極的 に推進していること,また ESA 投与により目標量の貯 血が比較的しやすくなったことから, 多くの診療科で 日常的に投与されるようになった.

慢性腎臓病の患者の治療には，ともに静脈注射用と 皮下注射用のエポエチン $\alpha\left(\right.$ エスポー $\left.{ }^{\circledR}, \mathrm{EPO} \alpha\right)$ とエ ポエチン $\beta$ (エポジン $\left.{ }^{\circledR}, \mathrm{EPO} \beta\right)$ が認可されている. と ころが，皮下注射用のこれらの製剤は投与部位に痛み
を生じる特性があり,それが患者の負担となっていた。 疼痛の原因としては添加物, $\mathrm{pH}$ などが関与していると 考えられていたことから, EPOßは2009 年に添加物を 調整することにより, $\mathrm{pH}$ を 6.8〜 7.2 まで上げた製剤に 全面的に変更した。このことにより疼痛が軽減された との報告がなされた ${ }^{3) \sim 7)}$ (Table 1).

自己血貯血に際しては皮下注射用 24,000 単位もしく は, 静脈注射用 6,000 単位週 3 回の投与が認められてい る. それまで, 皮下注射用 24,000 単位は $\mathrm{EPO \alpha}$ のみで あったが， 2010 年に皮下注射用の EPO 24,000 単位 (エポジン ${ }^{\circledR}$ 皮下注シリンジ 24,000) が認可され, 皮下注 射用の 2 剂が使用可能となった。

今回我々は，自己血貯血に際し皮下注射用の 24,000 単位 2 剂の投与時の皮下投与部位の疼痛を比較調查し, 投与時の疼痛に関与する因子を解析することにより新 たな知見を得たので報告する.

1）群馬大学医学部附属病院輸血部

2) 群馬大学医学部附属病院看護部

3）群馬大学医学部生体統御内科学

〔受付日：2013 年 4 月 23 日, 受理日：2013 年 8 月 26 日〕 
Table 1 Comparison between epoetin $\alpha$ (EPO $\alpha$ ) and epoetin $\beta$ (EPO $\beta$ ) components.

\begin{tabular}{|c|c|c|}
\hline & 添加物 & $\mathrm{pH}$ \\
\hline $\mathrm{EPO} \alpha$ & $\begin{array}{l}\text { ポリソルベート } 80 \\
\text { L-アルギニン塩酸塩 } \\
\text { リン酸二水素ナトリウム } \\
\text { 等張化剤 } \\
\mathrm{pH} \text { 調整剤 }\end{array}$ & $5.5 \sim 6.5$ \\
\hline ЕРО $\beta$ & $\begin{array}{l}\text { L- 塩酸ヒスチジン } \\
\text { ホリオキシエチレン } \\
\text { ポリオキシプロピレン } \\
\text { グリコール } \\
\text { 等張化則 } \\
\text { pH 調整剤 }\end{array}$ & $6.8 \sim 7.2$ \\
\hline
\end{tabular}

(cited from the package insert.)

\section{対象及び投与方法}

2011 年 11 月から 2012 年 11 月までに当院での手術を 目的とし, $800 \mathrm{~m} l$ 以上で 1 週間以上の貯血を予定して いる患者を対象とした． ESA の投与基準は，保険収載 に従い体重 $70 \mathrm{~kg}$ 以上の場合はへモグロビン $13 \mathrm{~g} / \mathrm{d} l$ 未満, 体重 $70 \mathrm{~kg}$ 未満の場合は $14.0 \mathrm{~g} / \mathrm{d} l$ 未満とした. 患 者には事前に文書及び口頭により本人に説明し，書面 による同意を得て前向きに登録した。これまでの報告 を参考に Visual Analogue Scale（VAS）で 1 回目の投 与時に $\mathrm{EPO} \alpha$ と $\mathrm{EPO} \beta$ の差が $1.0 \mathrm{~cm}$ と仮定し, サンプ ルサイズを 1 群 100 例とした $(\alpha=0.05, \quad \beta=0.2)$ 。一次 評価項目は 1 回目投与のVASによる痛みのスケール, 二次評価項目は痛みを規定する因子とした。診療科は 泌尿器科, 婦人科, 消化器外科, 整形外科, 脳神経外 科の合計 203 名の患者で, 延べ 405 回の ESA を投与し た．診断名，診療科，合併症，理学所見や服用してい る薬剤, 目標䝪血量の達成率などの医学的情報に関し ては問診あるいは患者記録で調べた.

この研究は無作為割り付けによる単盲検試験として 実施した。すなわち製郕は 3 名の自己血採取担当医師 が無作為に選択し，患者には製剤名がわからないよう に配虑しながら患者毎に同一のものを投与した，投与 に際しては，ESA 製剂を十分に室温に戻し $26 \mathrm{G}$ 針で 1 シリンジの全量である $0.5 \mathrm{ml}$ (24,000 単位)を上腕の皮 下に約 5 秒かけて注入した。 またその際，患者の不安 をとるべく十分な声かけを行った.

また, 最後の 48 人に対しては, 投与に伴う痛みが貯 血を完遂するうえで影響を及ぼすほどか否かを明らか にするため, 次回の ESA 製剂投与をどう思うかに関し て以下のアンケートを行い, 1 つを選んでもらった. (1) 絶対に受けたくない，(2)必要なら受ける，(3)痛みは気 にならないので受ける，尚，この研究は，当院の倫理 委員会の審査にて承認されたうえで行った。

\section{評価方法}

Visual Analogue Scale $(\mathrm{VAS})^{8}$ 及び Face Scale $(\mathrm{FS})^{9)}$ にて評価を行った（Fig. 1)。VAS は 100mm の直線の 中心の位置を 0 として左右に $-50 \mathrm{~mm},+50 \mathrm{~mm}$ とした. 注射針を刺した時の痛みを 0 とした場合に，薬液を入 れている最中の痛みが 0 からどの程度であるかを記載 してもらい, 0 からの長さを $-50 \mathrm{~mm}$ から $+50 \mathrm{~mm}$ で数 值化した. VAS は一般に正規分布しないことが知られ ており 2 群間の比較には Wilcoxon 順位和検定を行った. FS は投与 30 秒 $~ 60$ 秒後の自覚痛を 6 段階に評価し, 感じた疼痛に近い表情を選択してもらい，それぞれの 表情を 0 ～5 数值に置き換えた. 評価は $\chi^{2}$ 検定で行っ た. VAS, FS の結果に影響を与える規定因子を重回帰 分析, 順序 logistic 回帰分析にて解析した. 多群間比較 には ANOVA およびSteel-Dwass 検定を用いた. $p<$ 0.05 を有意水準とした。統計解析には JMP version 9.0 (SAS Institute Inc. Cary, NC) を使用した.

\section{結果}

2 剂を投与した患者群間の背景を比較した結果, 全て の項目について有意差は認めなかった (Table 2). 痛み の評価に関しては同一患者の複数回投与による持ち越 し効果及び痛みに対する慣れの影響を除くため, 1 回目 の投与を中心に解析した.

1 回目に投与した製剂間の VAS の中央值は $\mathrm{EPO} \alpha$ で $12 \mathrm{~mm}(3 \sim 23 \mathrm{~mm}), \mathrm{EPO} \beta$ で $7 \mathrm{~mm} \quad(-9.5 \sim 18.25$ $\mathrm{mm})$ で, 2 凨間で痛みに有意差を認めた $(p=0.0085$, Fig. 2A). また, のべ 405 回の投与全体においても同様 の結果だった $(p<0.0001 ，$ Fig. $2 \mathrm{~B})$ 。一方，投与した 製郕間の FS に有意差を認めなかったが, $\mathrm{EPO \beta}$ の方が 0 や 1 の疼痛評価が多く,また 2 から 5 では $\mathrm{EPO}$ でそ の頻度が同等かやや低く, EPO 認めた (Fig. 3A)。 405 回の投与全体を見ても同様の傾 向であったが統計学的に有意差はなかった(Fig. 3B). また, 2 郕間で目標貯血量の達成率や同種輸血の回避率 に差はなかった。

痛みは極めて主観的な感覚であり精神的, 環境的な 要因でも大きく変化しうるためこうした因子の影響は 否定できない，そこで $\mathrm{ESA}$ 製剤投与時の痛みを規定す る因子について多変量解析を行なった. 1 回目投与時の VASに打いて最も有意水準が低く, 痛みに影響を与え る因子はやはり ESA の種類（EPO $\alpha)$ であった。その 他としては唯一女性が有意に影響を与えていた(Table $3 \mathrm{~A})$. 投与全体の解析でも ESA 製剤 $(p<0.0001)$ ，女 性 $(p=0.0007)$, 年齢 $(p=0.0003)$ が有意な因子とし て同定された (Table 3B). 精神的な状態を反映すると 思われた原病が悪性か否かや，痛みに直接影響すると 考えられる糖尿病の有無, 非ステロイド系消炎鎮痛剂 


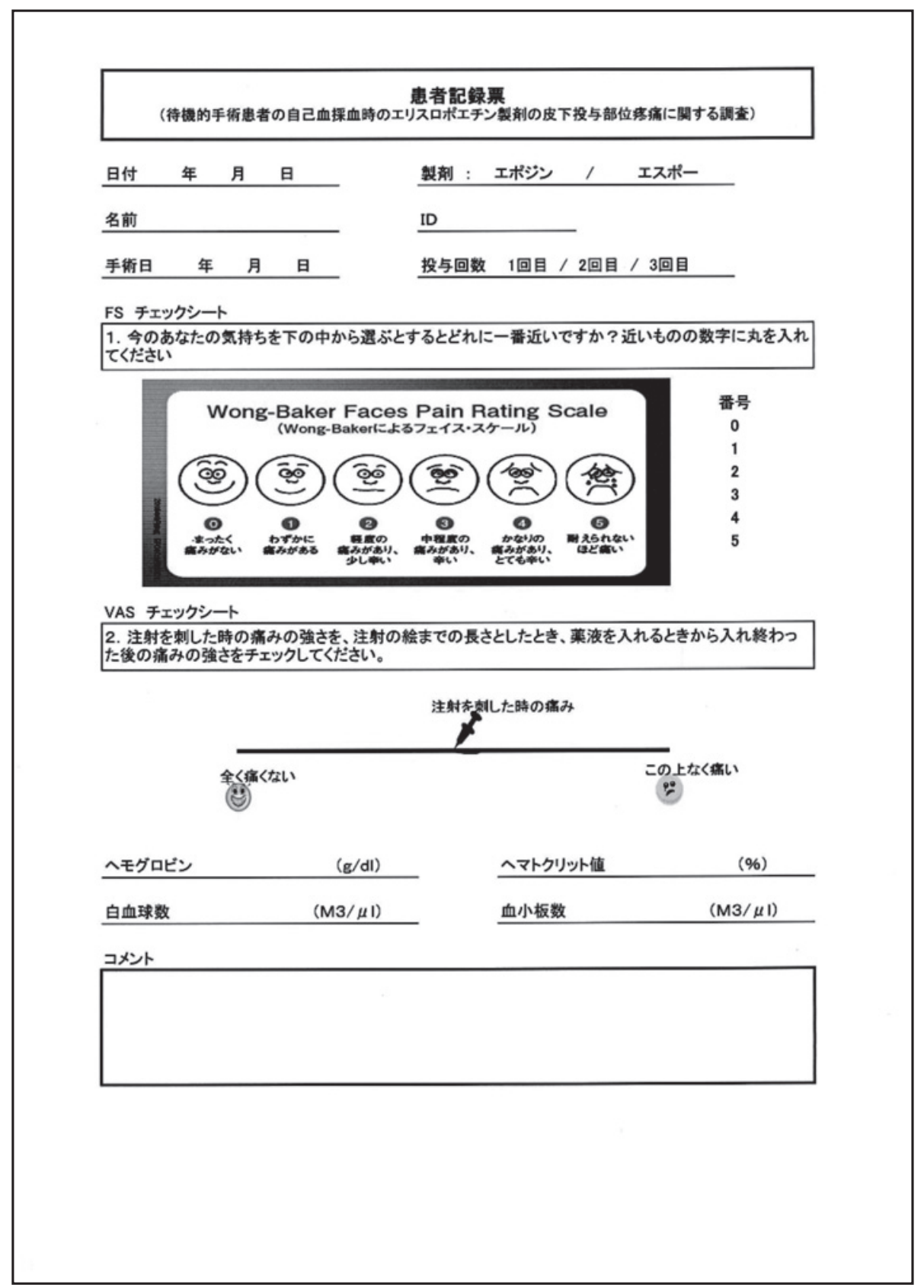

Fig. 1 Case report form (CRF) used in this study

Scores from the Face Scales were evaluated at 30-60 seconds after subcutaneous injection of Erythropoiesis-Stimulating Agent (ESA). Patients were also asked to rate their perceived pain on the Visual Analog scale (VAS) during injection of ESA, considering the pain of puncture of the needle.

投与の有無, 診療科の別, 穿刺者の違い, あるいは Body Mass Index（BMI）に関しては痛みに影響を与える因 子にはならなかった.一方, FSについては 1 回目の ESA 製剤投与時に有意に痛みを規定する因子を同定できな かった。

VAS の解析において女性であることが痛みの感覚に おける有意な因子として同定されたため,さらに 1 回 目の投与時の VAS を ESA 製剂の種類と性別で 4 群に
分け解析した (Fig. 4). 女性/EPO $\alpha$ 投与群は他のすべ ての群に比べて VAS が有意に高かったのに対して(Fig. 4A), その他の群の間でVAS に有意差はなかった. 投 与全体においても同様の傾向であった（Fig. 4B).

48 名の患者に対して行ったアンケートの結果から, $\mathrm{EPO} \beta$ 群の 1 例が次回の注射を受けたくないと答えたが, 他の 47 名は投与に否定的ではなかった. 2 剂間の痛み に統計学的有意差は認めるものの, 貯血計画に影響を 
Table 2 Number of injections and patient characteristics at the $1^{\text {st }}$ injection.

\begin{tabular}{l|c|c|c|c}
\hline & All & EPO $\alpha$ & EPO $\beta$ & $p$-value \\
\hline Number & & & & $0.9722^{* * *}$ \\
$1^{\text {st }}$ injection & 203 & 100 & 103 & \\
$2^{\text {nd }}$ injection & 152 & 76 & 76 & \\
$3^{\text {rd }}$ injection & 49 & 26 & 23 & \\
\hline Patients characteristics at $1^{\text {st }}$ injection & & & & \\
Age (y), mean (SD) & $59.1(13.8)$ & $60.8(13.1)$ & $57.3(14.2)$ & $0.0732^{*}$ \\
Sex, male (\%) & 0.90 & 1.08 & 0.75 & $0.200^{* *}$ \\
BMI, mean (SD) & $22.5(3.2)$ & $22.5(3.5)$ & $22.6(3.0)$ & $0.8924^{*}$ \\
Hb (g/d), mean (SD) & $12.7(0.90)$ & $12.7(0.92)$ & $12.7(0.79)$ & $0.9545^{*}$ \\
Malignant diseases (\%) & 60.6 & 61 & 60.2 & $1.000^{* *}$ \\
Department (\%) & & & & $0.349^{* * *}$ \\
Urology & 33.2 & 32.0 & 34.3 & \\
Surgery & 25.2 & 20.6 & 30.0 & \\
Orthopedics & 23.3 & 23.5 & 23.0 & \\
Gynecology & 17.3 & 19.6 & 15.0 & \\
Neurosurgery & 1.0 & 2.0 & 0.0 & \\
DM (\%) & 12.3 & 11.0 & 13.6 & $0.670^{* *}$ \\
Painkiller (\%) & 16.3 & 15.0 & 17.5 & $0.705^{* *}$ \\
\hline
\end{tabular}

*unpaired t-test, ${ }^{*}$ Fisher's exact test, ${ }^{* * *}$ chi-square test

BMI, Body Mass Index; DM, Diabetes Mellitus; SD, Standard deviation.

A

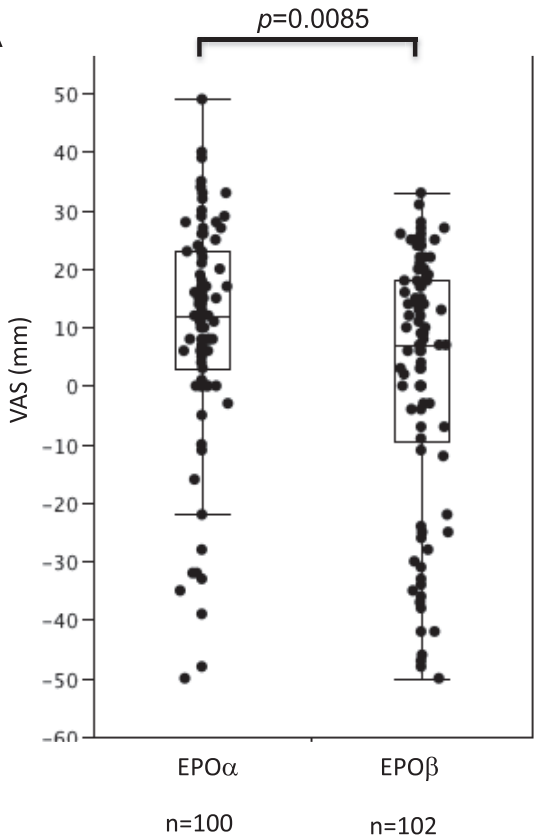

B

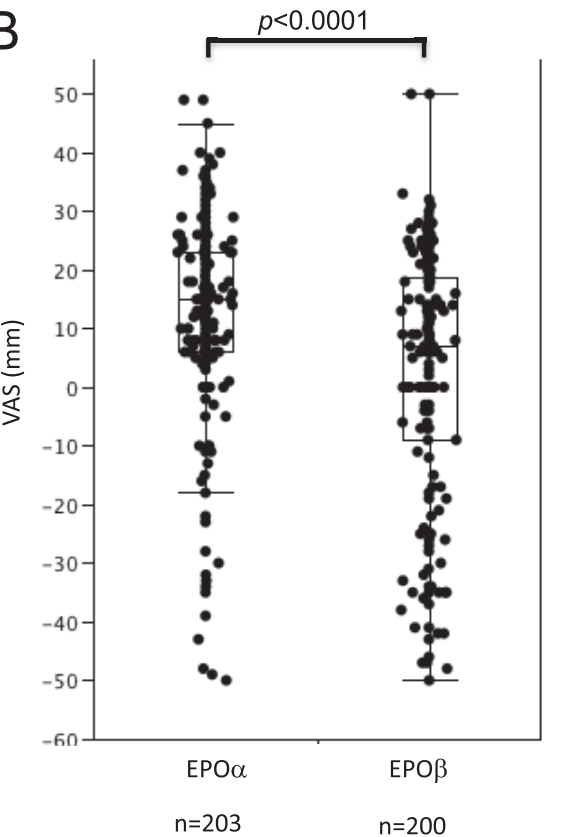

Fig. 2 VAS score at $1^{\text {st }}$ injection (A) and for all injections (B)

VAS scores were significantly higher in the EPO $\alpha$ group than in the EPO $\beta$ group at both the $1^{\text {st }}$ injection $(p=0.0085)$ and for all injections $(p<0.0001)$.

及ぼすほどの痛みとは感じていないことがわかった(Table 4).

\section{考察}

今回検討した 2 剂とも 1990 年に発売されて以来, 度 重なる製剤成分や規格の変更を行ってきた，当初，添 加物として人血清アルブミンが含まれていたが, 1995 年に安定供給の問題及び蛋白非添加製品を目指す観点
から、ゼラチンに変更された．2001 年にはゼラチンか らポリソルベート 80 と塩酸アルギニン $(\mathrm{EPO \alpha})$ もし くは L-塩酸ヒスチジン $(\mathrm{EPO} \beta)$ に変更となった. 更に 2009 年には, それまで製造工程で使われていた動物由 来の血清成分を使用しない無血清化製剤が承認された。 この際これに加えて EPOß は, ポリソルベート 80 をポ リキサマー 188 に変更することにより, 従来, 5.5〜 6.5 であった $\mathrm{pH}$ を中性域の $6.8 \sim 7.2$ に, 生理的食塩液に対 

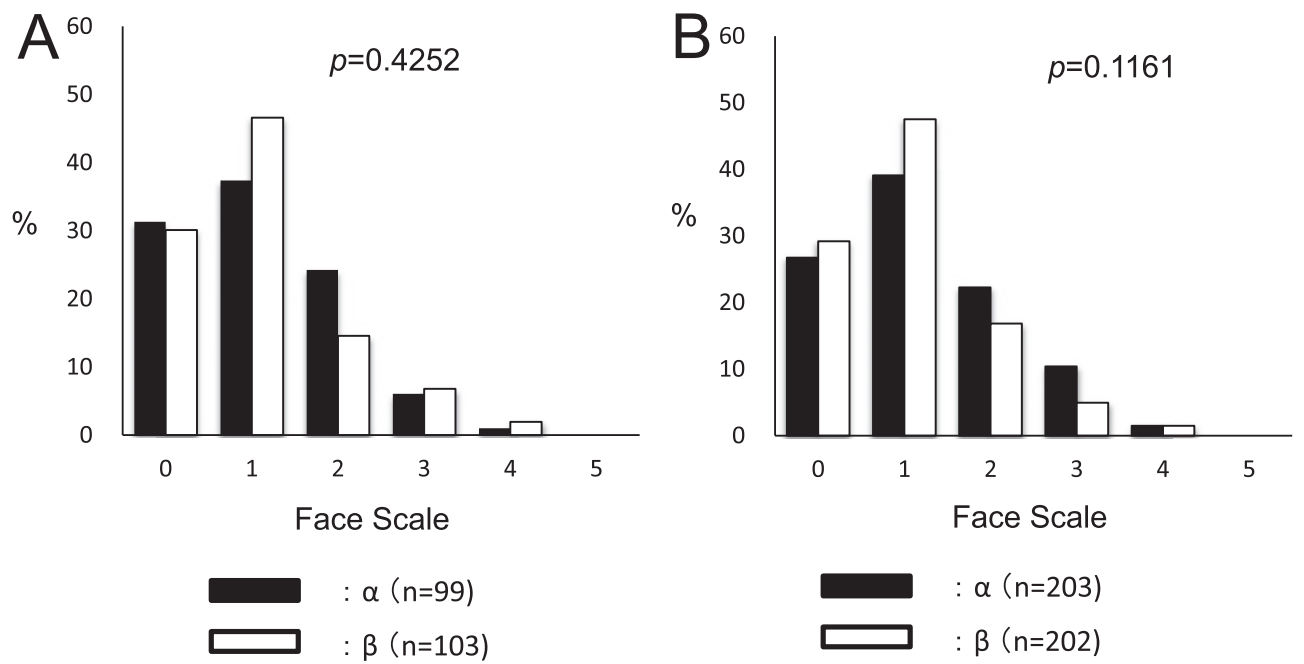

Fig. 3 Faces Scale score at $1^{\text {st }}$ injection (A) and for all injections (B) Differences between the two agents were not observed on the Faces Scale at both the $1^{\text {st }}$ injection $(p=0.4252)$ and for all injections $(p=0.1161)$. EPO $\alpha$ is represented by the filled bar and EPO $\beta$ is represented by the open bar.

Table 3 Multiple linear regression analysis of VSA score at $1^{\text {st }}$ injection $(\mathrm{A})$ and for all injections (B).

\begin{tabular}{|c|c|c|c|c|}
\hline \multirow[t]{3}{*}{ A } & Variable & Estimate & $95 \% \mathrm{CI}$ & $p$-value \\
\hline & ESA (EPO $\alpha)$ & 5.001 & $2.165-7.846$ & 0.0006 \\
\hline & Sex (female) & 5.107 & $1.419-8.7938$ & 0.0069 \\
\hline \multirow[t]{4}{*}{ B } & Variable & Estimate & $95 \% \mathrm{CI}$ & $p$-value \\
\hline & ESA (EPO $\alpha)$ & 5.737 & $3.812-7.662$ & $<0.0001$ \\
\hline & Sex (female) & 4.061 & $1.724-6.399$ & 0.0007 \\
\hline & Age & -0.316 & $-0.487--0.144$ & 0.0003 \\
\hline
\end{tabular}

CI, Confidence interval

する浸透圧比を約 1 にすることに成功した。

腎不全患者における 2 鼡の痛みの比較は 1990 年代か ら国内外で多数報告され，上記の上うに発売時期によ り痛みの原因とされる添加物が異なる。結果， $\mathrm{EPO \alpha}$ は $\mathrm{EPO}$ に比べ痛みの程度が大きいというものが多い が, 2 鼡間に差はないという報告もあり必ずしも一貫し

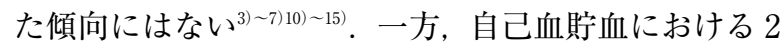
剤間の痛みの比較を行った報告は未だに少なく 2 報の

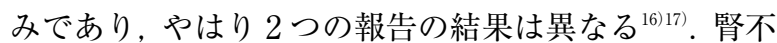
全患者を対象とした研究を含めそれぞれで研究デザイ ンが異なっており，今ひとつ一貫性のない結果に影響 を与えた可能性もある。痛みの調查を行う上で注意す べき点の一つに持ち越し効果の問題である。これは以 前の試験が次回の試験期間において及ぼす残存効果で あり，この効果を排除するためには十分な休薬期間， いわゆるウオッシュアウト期間を置かなければならな い ${ }^{18199}$. しかし, 自己血貯血を想定した本研究では十分 なウオッシュアウト期間を置くことは不可能なため,
投与 1 回目だけに主要な評価を行うこととした。両側 検定で 1 群 100 例と設定し，合計 203 例という腎不全 患者の報告を含めても今までの報告の中では最大数の 解析を行った，症例数を増やすことによりクロスオー バー試験などの形式は取らず極めてシンプルな無作為 割り付けによる単盲検試験にすることでより確かな結 果を目指した。

今回の我々の検討では，一次評価項目である 2 種類 の ESA 製夙間の VASにおいて EPOßでVAS score が明らかに低く統計学的な差を認めた. FSにおいても 統計学的な有意差は認めなかったが同様の傾向があっ た．痛みとは患者個人の感受性が強く影響するきわめ て主観的な感覚であるため, VASやFSを使った患者 間の評価は一般的に困難であると言われている ${ }^{14220)}$. そ の欠点を克服するため最近では異種感覚を電気的に加 えることにより一つの基準を作りVASをより客観的に 評価する試みも行われている ${ }^{20}$. 本試験では薬液注入時 の痛みのみを評価する必要がある.2剂間において針刺 時の痛みに違いはないことから針刺入時の痛みを基準 とし, 注入時の痛みの増強もしくは減弱を比較したわ けであるが, 基準を作れたVAS に対して, 作れなかっ た FS は客観性にやや欠け統計学的な差が出なかった可 能性がある．今までの報告を見ても同様に基準点をも うけた報告では少数例の研究であってもVASに有意差 が出ていることもこれを裏付けるものかもしれない.

二次評価項目である ESA 投与時の痛みに関与するそ の他の因子として, 本研究では女性であることが同定 された. 我々の知る限り ESA 製剤投与時の痛みに関与 する多数の因子を解析したものは腎不全患者を対象と した 1 報のみであり男女間には差がなかっだ。.この報 

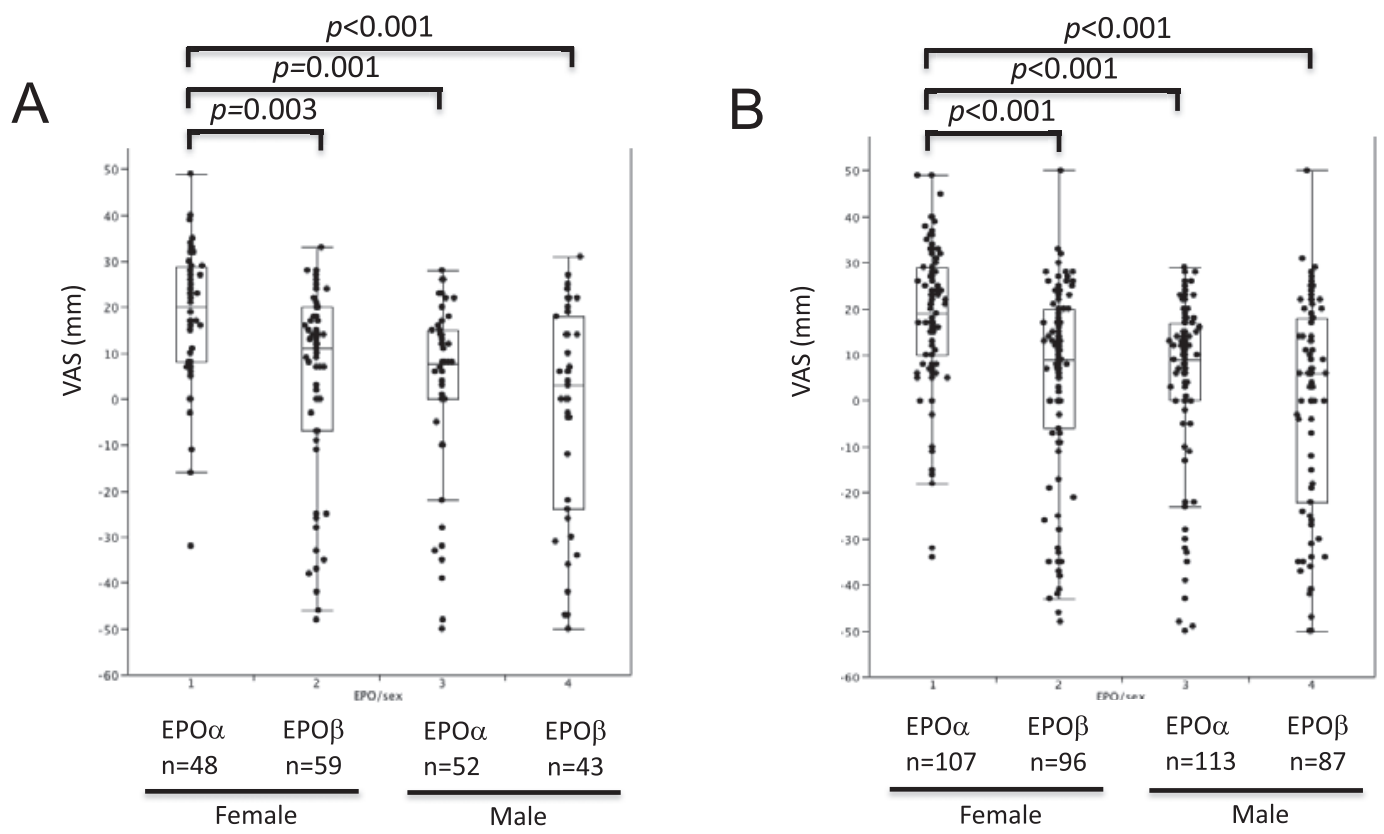

Fig. 4 VAS score among four groups separated by sex and EPO preparation at the $1^{\text {st }}$ injection (A) and for all injections (B).

The EPO $\alpha /$ female group had significantly higher scores than the other three groups at both the $1^{\text {st }}$ injection and for all injections, although no statistical significance was observed among groups in both settings.

Table 4 Results of questionnaire

\begin{tabular}{l|c|c}
\hline & $\begin{array}{c}\mathrm{EPO} \alpha(\%) \\
\mathrm{n}=25\end{array}$ & $\begin{array}{c}\mathrm{EPO}(\%) \\
\mathrm{n}=23\end{array}$ \\
\hline 絶対受けたくない & 0.0 & 4.3 \\
必要なら受ける & 56.0 & 56.5 \\
痛みは気にならない & 44.0 & 39.1 \\
\hline
\end{tabular}

告と本研究の結果が異なる理由は, 原病の違いも然る ことながら既報は母集団の女性の比率が $36.6 \%$ とやや 低く，かつクロスオーバー試験であることによる痛み の感覚のウオッシュアウトの問題や女性特有の痛みに 対する慣れで性差が隠されてしまった可能性が考えら れる ${ }^{21}$. しかし，この既報においても女性のVAS はや や高い. 痛みに対する性差の研究では, 痛みの感じ方 には性差が認められ，一般的に女性の方が強く痛みを 感じることが明らかになっている22233. こうしたことを ふまえると本研究で女性が痛みに関与する因子として 同定されたのは当然かもしれない，一方，前述の整形 外科患者に扔ける自己血採取時の比較では女性患者を 多く含んでいるにもかかわらず 2 郕間に有意差は出て いない．詳細な解析方法や結果の記載がないため不明 な点も多いが，上述のような基準点を設けなかったこ ともばらつきが大きくなり検定に影響を及ぼした可能 性はある. 我々の結果を性別と製剂で 4 群に分けると いずれの群も女性/EPO $\alpha$ 群との間に有意差が見られ女 性では EPO $\alpha$ の投与に配慮が必要であると考えられた.
また, 他の群間である男性/EPO $\alpha$ 群と男性/EPO $\beta$ 群の 間には有意差はなかった，現段階では男性ではどちら の製剂を使っても問題ないと言えるほどの症例数はな く,この点に関して結論には至らない.

しかし, 以上の結果から $\mathrm{EPO} \alpha$ の投与は行うべきで はないと結論するのはやや短絡的であろう，痛みには 程度があり数值化した比較の上では差があるものの臨 床の場で実質的には問題にならないという場合もある. 研究デザインや対象患者は異なるものの本研究も含め いくつかの報告では 2 郕間の痛みに差が証明されてい る. 次のステップとしてその程度を評価するためにア ンケートを行った．質問内容に対しては次回の投与を 拒否するといった回答は 1 例を除きどちらの群にも認 められず，どちらの製剤を投与しても貯血計画に影響 を与えるほどの痛みの差ではないことが示唆された. もちろん痛みのような有害な反応は, より少ないこと を目指すべきではある。しかし，このアンケート結果 は，例えば有害事象などで $\mathrm{EPO}$ の投与が難しい場合 $\mathrm{EPO} \alpha$ の投与は十分可能であることを示すものと考えら れた。

以上をまとめると，本研究でも既報と同様に $\mathrm{EPO} \beta$ 群で有意に痛みが小さく，さらにそれは女性で顕著で あった。しかしながら，その痛みの差は䝪血計画に影 響を与えるほどではないものと考えられた。

著者の COI (conflicts of interest) 開示 : 本論文発表に関連し 
て特に申告なし.

\section{文献}

1) Goodnough LT, Rudnick S, Price TH, et al: Increased preoperative collection of autologous blood with recombinant human erythropoietin therapy. N Engl J Med, 321: 1163-1168, 1989.

2) 脇本信博, 黒川高秀, 杉岡洋一, 他 : 遺伝子組み換え七 トエリスロポエチン KRN5702 週 1 回皮下投与を併用す る貯血式自己血輸血法. 日本輸血学会雑誌, 38：699711, 1992.

3）丸山弘樹, 成田一衛, 後藤 眞, 他：腹膜透析患者に対 する ESAの皮下投与における疼痛比較試験 エポエチ ンベータ製剤とダルベポエチンアルファ製剤の比較. PTM, 4: 9-12, 2011.

4）井上 徹, 長門谷克之, 鶴田良子, 他 : エリスロポエチ ン製剂皮下投与時の疼痛比較 エポエチンアルファ・エ ポエチンベータの比較. 臨床透析, $26: 497$-500, 2010.

5）吉田祐一, 星野 豊: エリスロポエチン製剤の皮下注射 による痛みの検討 組成変更後のエポエチンベータとエ ポエチンアルファとの比較。腎と透析，67：549-552, 2009.

6）牧野武志, 安藤 航, 長場 泰, 他: エポエチン $\alpha$ とエ ポエチン $\beta$ の皮下投与時の痛みの比較調查. 日本透析医 学会雑誌, 43：795一800, 2010.

7）蓮沼智子, 姚 皇治, 松村有子, 他： $\mathrm{EPOCH}$ 注の健康 成人を対象とした臨床薬理試験 痛みの程度に関する二 重盲検比較試験. 腎と透析, $66: 747-754,2009$.

8) Keel K: The pain chart. Lancet, 2: 6—8, 1948.

9) Wong DL, Baker CM: Pain in children: comparison of assessment scales. Pediatr Nurs, 14: 9-17, 1988.

10) Frenken LA, van Lier HJ, Gerlag PG, et al: Assessment of pain after subcutaneous injection of erythropoietin in patients receiving haemodialysis. BMJ, 303: 288, 1991.
11) Lui SF, Leung CB, Li PK, et al: Pain after subcutaneous injection of erythropoietin. BMJ, 303: 856, 1991.

12) Schmitt CP, Nau B, Brummer C, et al: Increased injection pain with darbepoetin-alpha compared to epoetinbeta in paediatric dialysis patients. Nephrol Dial Transplant, 21: 3520—3524, 2006.

13）山下明美, 穴水その美, 大場キミ子, 他 : エリスロポエ チン製剂間の皮下投与時疼痛の検討. Pharma Medica, $21: 117-120,2003$.

14）酒井行直, 酒井紗織, 大塚智之, 他：腹膜透析患者にお けるエリスロポイエチン製剤比か投与時の疼痛比較. 臨 床透析, 26:129-132,2010.

15）高倉果林, 小野田教高, 大薗英一, 他：保存期腎不全患 者におけるシリンジ型エリスロポエチン製剤皮下投与時 の疼痛比較. 新薬と臨床, $54: 76$ - 81,2005 .

16）長谷川正裕, 松井佑梨世, 須藤啓広 : 人工関節置換術前 のエリスロポエチン製剤皮下注射時における痛みの検討. Therapeutic Research, 33 : 437-440, 2012.

17）齋藤裕司, 大隅大介, 河井紀一郎, 他 : 自己血貯血患者 に対する遺伝子組み換えヒトエリスロポエチン製郕投与 時の疼痛に関する検討. 日本輸血細胞治療学会誌, 59： 30-37, 2013.

18）厚生省医薬安全局：臨床試験のための統計的原則, 1998.

19）医薬品医療機器総合機構：臨床試験の一般指針, 1998.

20）有田英子, 小川節郎, 花岡一雄：痛みの強さの客観的評 価. 日臨麻会誌, $29 ： 35-42,2009$.

21) Hashmi JA, Davis KD: Women experience greater heat pain adaptation and habituation than men. Pain, 145: 350-357, 2009.

22) Berkley K: Sex differences in pain. Behav Brain Sci, 20: 371-380, 1997.

23) Riley JL 3rd, Robinson ME, Wise EA, et al: Sex differences in the perception of noxious experimental stimuli: a meta-analysis. Pain, 74: 181—187, 1998. 


\title{
CLINICAL FACTORS ASSOCIATED WITH PAIN AFTER SUBCUTANEOUS ERYTHROPOIETIN INJECTION IN AUTOLOGOUS BLOOD DONORS WITH MULTIVARIATE STATISTICS
}

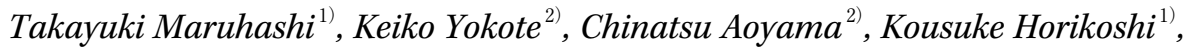 \\ Takahiro Sugai ${ }^{1)}$, Natsumi Nishimoto ${ }^{1)}$, Kozue Susa ${ }^{1)}$, Tomomi Sekigami ${ }^{13)}$, \\ Yoko Hashimoto $^{13)}$, Makiko Takizawa ${ }^{1) 3)}$ and Akihiko Yokohama ${ }^{1)}$ \\ ${ }^{1)}$ Blood Transfusion Service, Gunma University Hospital, Faculty of Medicine, University \\ ${ }^{2)}$ Division of Nursing, Gunma University Hospital \\ ${ }^{3)}$ Department of Medicine and Clinical Science, Gunma University Graduate School of Medicine
}

\begin{abstract}
:
Although subcutaneous injection of erythropoiesis-stimulating agent (ESA) is a convenient administration method, pain at the injection site remains problematic. Currently, two ESAs are available in Japan. Differences in pain have been observed between these two ESAs in several reports; however, most of the studies consisted of patients with renal failure.

To clinically determine important factors associated with pain after subcutaneous ESA injection, we conducted a single-blind clinical trial comprising autologous blood donors. Two ESAs were administered 405 times to a total of 203 patients. Both the Visual Analogue Scale (VAS) and the Faces Scale (FS) were used to measure perception of pain after ESA injection. The median VAS score was significantly lower in the epoetin $\beta$ (EPO $\beta$ ) group than in the epoetin $\alpha(\mathrm{EPO} \alpha)$ group, although a significant difference between groups was not seen on the FS. Multiple regression analysis for the VAS at first injection revealed that both ESA and sex were statistically significant factors for pain. Intriguingly, when the VAS score was compared among four groups that had been divided by sex and ESA preparation, the VAS score of females injected with EPO $\alpha$ was significantly higher than that of the other three groups. EPO $\alpha$ causes more severe pain than EPO $\beta$, especially in females, although this difference in pain does not affect blood collection.
\end{abstract}

\section{Keywords:}

epoetin $\alpha$, epoetin $\beta$, eythropoiesis-stimulating agent, Visual Analogue Scale, Faces Scale, female

(C)2013 The Japan Society of Transfusion Medicine and Cell Therapy

Journal Web Site: http://www.jstmct.or.jp/jstmct/ 